\title{
Ad utriusque imperii unitatem? Anastasius Bibliothecarius as a Broker between Two Cultures and Three Courts in the Ninth Century
}

\section{Clemens Gantner*}

In 870, Anastasius, former (and later once again) librarian of the papal bibliotheca and chancellery, well-known erudite and former anti-pope, reached the pinnacle of his career as a diplomat. While exiled from Rome for a crime committed by his cousin, he was an important member of a mission sent to Constantinople by the Carolingian emperor and lord of Italy Louis II. He was sent there to negotiate a marriage alliance between Louis's daughter and only surviving child Ermengard and a son of the upstart Byzantine emperor Basil I, which was ultimately to serve to bind the two empires together in the fight against the Saracens, southern Italy and Sicily. While there, Anastasius also joined the papal delegation at the Eighth Ecumenical Council, which was there in the pope's stead to formally depose Patriarch Photius and negotiate the case of Bulgaria. We thus see Anastasius as a diplomat and cultural broker between Latin and Greek ecclesiastic and lay culture and between three courts. He composed a letter about his dealings in the East for Pope Hadrian II in 870, and thus we have an invaluable first-hand eyewitness account. While most negotiations started in 869 and 870 between the East and the West ultimately failed or were rendered pointless by political change, Anastasius shows us that 870 was a great chance for all sides. And while most parties involved lost something by the failure of the exchanges, Anastasius himself regained and kept a powerful position in the papal administration once again.

Keywords: Anastasius Bibliothecarius, Louis II, emperor, Hadrian II, pope, Rome, papacy, Carolingian Empire, Byzantine Empire, diplomacy, cultural broker

\section{Introduction: The Talented Anastasius}

Anastasius, nowadays known as "the Librarian", was one of the most illustrious figures of the ninth century - some might rightfully say also one of the most notorious. ${ }^{1}$ He had been born into a family which was based in the city of Rome and which was to become relatively influential in the ninth century, as far as we can judge from the scant and patchy evidence

* Correspondence details: Clemens Gantner, Institut für Mittelalterforschung, Österreichische Akademie der Wissenschaften, 1020 Wien; email: clemens.gantner@oeaw.ac.at.

1 Forrai, Anastasius Bibliotecarius; Forrai, Interpreter of the Popes; Forrai, Greek at the Papal Court; Forrai, The Sacred Nectar; Perels, Papst Nikolaus I. und Anastasius Bibliothecarius; Neil, Seventh-century Popes and Martyrs; Arnaldi, Come nacque la attribuzione ad Anastasio del »Liber Pontificalis«; Arnaldi, Anastasio Bibliotecario, antipapa. 
that has come down to us for the Roman elites of this period. Anastasius must have received an exceptional education for a young cleric of his time - in his work, which we mostly have transmitted from the 860s onwards, he shows himself as an adept Latinist, author, theologian, and diplomat. His unique characteristic was, however, his mastery of Greek. ${ }^{2}$ Apart from Greek names running in his family, which was exceedingly common in families with definitely Latin-Roman origins from the seventh century on, there is nothing to suggest that his family may have been of Greek origin. Given the career of his uncle Arsenius, bishop of Orte, that even seems rather unlikely. What is more, in a legal process against Anastasius in 868, he was testified against by a kinsman of his, bearing the name Ado, which is certainly not a Greek name, and one could rather speculate about a Frankish connection there. ${ }^{3}$ His Greek was also far from flawless, as his translations show, suggesting that he used a learned language. ${ }^{4}$

Still, due to his thorough education in Greek, he was able to translate a whole corpus of very different texts from Greek into Latin and showed himself capable of discussing difficult theological matters in Greek, a rare ability in ninth-century Rome. ${ }^{5}$ The combination of all this education made him the closest anyone got to a bilingual person in the whole Latin West in his time.

That is not to say that the knowledge of Greek had declined as dramatically as some scholars still think today, despite Tom Noble's important contribution some four decades ago. ${ }^{6}$ Considering just the city of Rome, it can be shown that many Greek texts, especially saint's lives, were indeed produced well into the tenth century. However, these texts were written by a Greek community that does not seem to have been able to produce high-quality material in Latin ${ }^{7}$ - the same applies in reverse for the admittedly rather small group of erudites in the Latin language, most of whom were working for the Lateran administration. However, as we shall see below, Anastasius worked with a small team, and the members of this group were also able to translate from Greek texts. ${ }^{8}$ Thus, while he was not working alone, we can see our protagonist as the head of all these translation operations, which seems to have made him a man whose qualities the popes could not dispense with.

2 Arnaldi, Anastasio Bibliotecario, antipapa.

3 Annales Bertiniani, a. 868, trans. Nelson 148-150, ed. Grat, 144-150 (Ado at 149).

4 See, in great detail, Forrai, Interpreter of the Popes 95-114. Tabachovitz, Sprachliches zur lateinischen Theophanesübersetzung, 16-22, is surely overly critical in his judgement, but already clearly shows flaws in Anastasius' Greek. On this particular translation, see also Mango and Scott, Chronicle of Theophanes Confessor, 96-98. On Anastasius as a translator, see also Chiesa, Scopi e destinatari delle traduzioni, 121-124.

5 Forrai, Interpreter of the Popes.

6 Noble, Declining knowledge of Greek.

7 The classic study is Sansterre, Les moines grecs et orientaux à Rome, esp. 48-51 and 69-76.

8 Chiesa, Scopi e destinatari delle traduzioni, 121-124. 


\section{Cultural Output}

Apart from his services as a political negotiator and broker, Anastasius was also a cultural broker, as his literary career proves: in the 860 s and 70 s he produced a remarkable output. He interpreted several important saint's lives while Nicholas I was still pope. ${ }^{9}$ After the translation of the acts of the Eighth Ecumenical Council, with which we will deal in more detail below, he also translated those of the seventh, the Second Council of Nicaea, which had been held in 787. ${ }^{10} \mathrm{He}$ also produced an ample dossier on the seventh-century pope Martin I, who had convened the Lateran synod of 649 and was therefore famous for his steadfast defence of orthodoxy against monotheletism (the latter decreed by two consecutive emperors but considered a heresy by the papacy and many others). ${ }^{11}$ In addition, he translated a set of three Byzantine chronicles into Latin and occasionally added comments. This Chronographia tripertita was then widely copied, but even more than that, it was integrated into Western historiography and transported an important set of knowledge from both the Greek and the Syrian east. ${ }^{12} \mathrm{~A}$ sizeable part of his material he may have even obtained for himself and the Latin West at Constantinople. He made the material accessible to the Latin world and his translations are sometimes the only remaining version of a text. ${ }^{13}$ Through his translation work, Anastasius was as much a cultural broker as he was the power broker between at least three courts. All the same, we shall concentrate on his role as a politician and diplomat in due course.

\section{Anastasius' Political Odyssey}

Anastasius will probably have stood out even as a youngster due to his exceptional talents. In 847 or shortly thereafter, Anastasius was made priest of the church of S. Marcello. By 850, he had, however fled from the city, the reasons for which remain undisclosed in the sources we have at our disposal. ${ }^{14}$

A possible theory is that he did so in order to avoid being consecrated as bishop of a suburbicarian see by Pope Leo IV. This consecration would have reduced his chances of sitting on the papal throne later in his career to a minimum, as a switch (translatio) from one bishopric to another was considered uncanonical at the time, only dispensable by the pope himself, which made it problematic in this specific case. Therefore, Anastasius may have fled Rome to avoid elevation to a major order (so to speak). A statement from the pope himself seems to contradict this at first: in a summoning letter a few years later, Leo argued that Anastasius' ambition had been too high. ${ }^{15}$ At first glance this does speak against a quarrel over a promotion - but does it really? Whatever the true motivations may have been, he was swiftly excommunicated by Pope Leo.

10 For details on Anastasius' translation and the discrepancies concerning the letter of Pope Hadrian I, see Lamberz, »Falsata Graecorum more«?.

11 Neil, Seventh-century Popes and Martyrs. And see further work by Neil on various aspects of Anastasius' compendia and work as an author, compiler, and translator.

12 Mango and Scott, Chronicle of Theophanes Confessor, lxxiv-xcv.

13 See Forrai, Anastasius Bibliotecarius, 320, on the methodological difficulties. For an assessment of the working conditions, see Forrai, Interpreter of the Popes, 89-94 Note that she does not speculate as to where the manuscripts came from.

14 Arnaldi, Anastasio Bibliotecario, antipapa.

15 Arnaldi, Anastasio Bibliotecario, antipapa. 
The anathema is transmitted in its full text in a manuscript, Vat. Lat. 1342 of the Vatican library. ${ }^{16}$ It contains the text of a letter addressing Anastasius directly, followed by a solemn pronunciation of the anathema in a nice rubric in capitals, as well as an illustrious list of subscribers, including many bishops of the Roman metropolitan area, but also Paul, the envoy of the archbishop of Ravenna John, and claims that Emperor Lothar signed the acts as well (named directly after the pope, still in the rubric). Thereafter 65 bishops and many other clerics are also listed as witnesses. ${ }^{17}$

The anathematization was a big deal in Rome; the decision was even advertised on the walls of St Peter's basilica. This seems to have been far from a standard procedure; the fact was even recorded in the Liber Pontificalis, the semi-official papal historiography. ${ }^{18}$ When the anathema was renewed at another Roman synod in 853, the sentence was again fixed to the walls of Old St. Peter's. The text has been preserved by Hincmar of Reims. ${ }^{19}$ We must assume that a very serious political rival was to be driven from Rome once and for all. Leo IV did everything to ensure that, if he were to return, he would never hold an office in the papal administration again. This does, however, show Anastasius' prior standing.

This also becomes clearer from the events of 855: Anastasius returned to Rome at the head of a small armed force, provided by Louis II, emperor and king of Italy. The LP tells us that

the deposed priest entered Rome as an enemy and with his wicked followers swiftly made his way to the Lateran patriarchate; and like a bloodstained tyrant he opened its doors with worldly force and many kinds of weapons, and so entering by this door he sat on the throne which his hands should not even have touched. ${ }^{20}$

The Frankish missi succeeded at first in replacing the already elected Benedict III - who had not been confirmed by the emperor in his office and was therefore not a pope yet, despite the claims of the LP. ${ }^{21}$

Anastasius did not manage to hold on to the throne. The Romans threw the Franks and Anastasius out of the city and reinstated Benedict. This could and should likely have been the end of Anastasius' career in Rome. It was, however, probably his unique skills, which we have already described, that made him indispensable, so that he was restored to the Roman clergy under Benedict's successor Nicholas I (858-867), with the highest post he held being abbot of the important monastery at Santa Maria in Trastevere. ${ }^{22}$ He was promoted to the post of bibliothecarius, which meant head of archives as well as most scribal production, by the next pope, Hadrian II (867-872). ${ }^{23}$ However, disaster struck again: he had to flee Rome

BAV Vat. Lat 1342. The manuscript contains canon law, mostly Roman synods. The 850 synod begins on fol. 203r, the anathema proper on fol. 211r-213r.

17 BAV Vat. Lat. 1342, fols. 212r and 212v.

LP Vita of Benedict III, c. 12, trans. Davis, Lives of the Ninth-Century Popes, 172.

Annales Bertiniani, a. 868, trans. Nelson 148-150, ed. Grat 144-147.

o LP Benedict III, c. 13, trans. Davis, Lives of the Ninth-Century Popes, 172.

21 For the imperial point of view, see RI 3, ed. Zielinski and Böhmer, nn. 135, 136 and 140.

22 Arnaldi, Anastasio Bibliotecario, antipapa.

23 Perels, Papst Nikolaus I. und Anastasius, 231. 
a few months into that pontificate after one of the greatest scandals in papal history, which I can sum up here only very briefly. Anastasius' cousin Eleutherius had tried to force a marriage with Pope Hadrian's daughter through abduction - not an uncommon strategy at the time, one has to concede. The coup failed, however, and Eleutherius killed the pope's daughter and wife - only to be slain in turn by imperial envoys, who had tried to negotiate with him. Arsenius, Eleutherius' father, bishop of Orte and imperial apocrisiarius, that is overseer, at the Lateran, had to flee Rome in a hurry. Anastasius, too, was suspected of having played a part in the conjuration - which is quite unlikely, given that he had been a political opponent of his uncle since 867 at the latest. ${ }^{24}$ Still, after a few months holding his position in Rome, he too was banished by a harsh papal decree preserved by Hincmar of Reims in the Annals of St Bertin. ${ }^{25}$ He went to join the court, or at least the entourage of Emperor Louis - who at the time was campaigning against the Saracens at various places in southern Italy.

\section{The Mission to Constantinople - Prerequisites}

We meet Anastasius again, travelling back from Constantinople at some point in late spring or summer 870 , when he wrote a long letter to Hadrian II, designed to justify his own conduct and to function as a companion letter to the translation of the synodal acts of the same year. ${ }^{26}$

We have seen that Anastasius' involvement had a backstory of its own, but we also need to take a brief look at the geopolitical situation since the 840 s, because it needs to be clear why a Western imperial delegation was heading east at this point. Byzantium and the West had been in a climate of loose cooperation, but also of mutual distrust since the Franks had risen to more power during the eighth century. The two empires had been neighbours somewhere in Istria and in the Venetian lagoon since about 774. Charlemagne's imperial coronation in 800 had further complicated matters, as had several religious issues that were and largely remained unresolved. There had been armed conflict after that, mainly between Venice and the Italian Frankish kingdom, mostly in the time of King Pippin of Italy (d. 810), Charlemagne's son and, at the time, likely heir. ${ }^{27}$ An accord had again been reached with the treaty of Aachen in 812 , but distrust had remained, even though there had been political and military cooperation as well. In early 842, Emperor Theophilos (829-842) had reached out to the new and troubled emperor Lothar I (840-855) and had sought Frankish help against the Saracen threat - somewhere, as the letter is vague, but most likely in Italy. In due course, a marriage alliance was concluded between Lothar's son Louis and a daughter of Theophilos. None of this was ever carried out, as Theophilos died even before his delegation reached Lothar in Trier, but the agreement lingered on, with the Carolingians trying to obtain control over 'their' south and the Byzantines still expecting that marriage to be concluded at some point. This all dissolved in 853, when Louis abandoned the southern project for a while and found himself a Frankish woman, albeit first as a concubine. This led to reduced relations between

24 Anastasius, ep. 3, to Ado, ed. Laehr, 401. See Laehr, Briefe und Prologe, 421-425. On the unhappy events, see Grotz, Erbe wider Willen, 168-172.

25 Annales Bertiniani, a. 868, trans. Nelson, 148-150, ed. Grat, 148-150.

26 Anastasius, ep. 5, to Hadrian II, ed. Laehr, 403-415. For the edition of the whole translation by Anastasius, see Anastasius, Gesta sanctae, ed. Leonardi and Placanica.

27 See soon Gantner, Silence of the popes, as well as the whole Spes Italiae volume. 
the Franks and the Byzantines until the late $860{ }^{28}{ }^{28}$ In the meantime, however, the EastWest axis was still tested several times. Many of these tests started during the Roman pontificate of Nicholas I (858-867). Nicholas was a young and energetic pope, who stood out not mainly for his ideology, which was simply very papal and Roman, but mostly for his strongmindedness in thinking it through and standing by it. This brought him into conflict with most Western rulers, not least King Lothar II (855-869) and Emperor Louis II (855-875). His most exacerbated quarrels were, however, with the Byzantine court. Nicholas had, early in his tenure, supported the deposed patriarch Ignatios against his successor Photios, actually following legal protocol and, in fine papal tradition, simply assuming responsibility for the case. This had led to a harsh exchange of letters with the young Byzantine emperor Michael III (842-867), or rather his advisors. ${ }^{29}$ The question of which church was ultimately responsible for leading the new Christian mission in the Bulgarian kingdom further complicated matters, as the Bulgarians had temporarily turned to Rome. ${ }^{30}$ In 867 , Michael and Photios convened a synod to have Nicholas officially deposed. Before this synod met, they also contacted (or tried to contact) Emperor Louis II, who was campaigning against the Saracens between Bari and Benevento. They clearly tried to enlist his help and get Nicholas arrested in the West. They knew that Louis had had trouble with the pope only recently - and they offered official recognition of Louis and his wife Angilberga as emperors at the synod. As far as we know, the Western imperial couple was even acclaimed at that synod in autumn 867, which does not necessarily mean that their help against the pope had been guaranteed. ${ }^{31}$ I would even suspect that Angilberga would have known about Nicholas' serious illness by summer 867 and tried to play to both sides, but nothing can be proven. We do not even have the acts of the synod in September 867, as the political tides in Constantinople shifted soon thereafter. Michael III was murdered by his hierarchically inferior colleague and successor Basil I (867-886), Photios was deposed and Ignatios reinstated. Before this news reached Rome or Louis, Nicholas was already dead (d. 13 November) to complete the full turn of events. New communication seems to have been initiated between the Frankish and the Byzantine empires fairly quickly, but, again, religio-political matters interfered as well, as full communion between Rome and Constantinople was also sought. This led to a synod to be held in Constantinople in autumn 869, which in the West is recognized as the Eighth Ecumenical Council. The East no longer fully recognizes it, on good grounds, as this council was indeed far from universal. Its last session even had to be postponed, mainly to assure a minimum quota of consent among the Eastern ecclesiastics. ${ }^{32}$ This happened around the same time as Louis II, who had been campaigning in southern Italy against the Saracens since 866, started negotiations with Basil about a marriage union between his daughter Ermengard and Basil's son. The Byzantines were, in return, expected to provide naval support for Italy and it was envisaged that in due course the Franks would, in turn, provide troops for the planned reconquest of Sicily. ${ }^{33}$

28 Gantner, »Our Common Enemies Shall Be Annihilated!«; Gantner, Kaiser Ludwig II.

29 Noble, Pope Nicholas I and the Franks.

30 LP Nicholas, cc. 19 and 75-76, ed. Duchesne, vol. 2, 155 and 165.

31 RI 1,3,1, ed. Zielinski and Böhmer, no. 273. See Mansi, Sacrorum Conciliorum, ed. Martin and Petit, vol. 16., col. $255 \mathrm{D}$ and $\mathrm{E}$, for the account by the Byzantine author Niketas-David.

32 Chrysos, Council of Constantinople.

33 This information can be gathered from Louis II, Letter to Basil, ed. Henze, 385-394. See Henze, Über den Brief Kaiser Ludwigs II.; Fanning, Imperial diplomacy. 
Therefore, an imperial mission travelled to Constantinople in late autumn of that year and reached Constantinople early in $870 .{ }^{34}$ And it is from this point on that a letter by Anastasius becomes our best source for what happened next.

\section{Anastasius' Letter to Pope Hadrian II (870, ep. 5)}

First, we need to discuss the transmission of the letter briefly, as it will also help in dealing with its contents. Anastasius' letter to Pope Hadrian II was inserted, in all probability by its author, as a dedicatory piece to go with the translations of the acts of the Eighth Council, which had recently been finished. This translation had been done by Anastasius himself and he may have felt that his probably originally older letter would fit in nicely. Interestingly, today we have the very manuscript of this translation in which Anastasius entered his own corrections to the text. It is important to note that the letter seems to have come down to us in a slightly re-worked version. ${ }^{35}$ This manuscript is the Vaticanus Latinus 4965, today kept in the Biblioteca Apostolica Vaticana. ${ }^{36}$ It was clearly produced by Anastasius' own trusted collaborators in a nicely executed Carolingian minuscule. It had a very interesting later history, as Rather, the famous bishop of Verona, entered his glosses in the tenth century. It is even possible, but not certain, that the manuscript had made its way to Bobbio a few years after its production in $870 / 71 .{ }^{37}$

It is very likely that Anastasius indeed worked on this very manuscript with his own team, probably scribes from Rome - and possibly from his own workshop at the monastery of S Maria in Trastevere, where he had been abbot until falling from grace in 868 .

The letter to Hadrian II contained in this important manuscript, as well as in many other copies of the translation of the acts of the eighth council, was, judging from its narrative, written while still on his way back, possibly shortly after his return to Italian shores. This seems only logical, considering that in Rome Anastasius could have reported to Hadrian directly. It is also quite clear why Anastasius would have chosen to write a long letter instead: he was still removed from his office as abbot and was persona non grata in Rome for his alleged part in the murder of the pope's daughter. He thus probably sent the original version of this letter ahead before going to Rome (rather briefly) himself. This we can safely assume, even though the author himself already mentions the translation of the acts - he could have meant that as a current project, or he could have edited that sentence into the text when he chose the letter as a preface to his translation. ${ }^{38}$ Interestingly, Anastasius told the rest of the tale himself, in a gloss, to be found in the original manuscript Vat. Lat. 4965 itself, ${ }^{39}$ in which he described

34 The embassy was therefore not a reaction to the alleged arrival of a Byzantine fleet before Bari in 869 . This fleet in all probability only arrived as a reaction to Anastasius' mission later in 870 . The timeline will be revisited below, at n. 52. See also Kislinger, Erster und zweiter Sieger. Leonardi, Anastasio bibliotecario e l'ottavo concilio ecumenico, 74-9o Palma, Antigrafo/Apografo, esp. Tav. 11 and 12. BAV Vat. Lat. 4965, s. IX ex. Palma, Antigrafo/Apografo: the manuscript was indeed corrected together with the exemplar from Bobbio - which does not mean that this must have been done at that monastery. On the manuscript and its genesis, see Leonardi, Anastasio bibliotecario, 90-104. Schmid, Roms karolingische Minuskel. See also Chiesa, Filologia e politica.

38 Anastasius, ep. to Hadrian II no. 5, ed. Laehr, 403-415.

39 BAV Vat. Lat. 4965, fol. 22v. The account is a gloss spanning the full page. See an edition in: Leonardi, Anastasio bibliotecario, 170-171. 
the rest of the journey. The Latin missions, both the papal and the imperial one, had gone to Dyrrhachium together. There, however, their ways parted. The papal envoys boarded a ship to Ancona, which was captured on the way by Slavic pirates, whereupon the original codex with the council acts was lost. Anastasius' party made it to Siponto safely and went to Benevento. It was only from there that some went on to Rome, bringing the copy of the acts with them..$^{40}$ Anastasius cannot have stayed in Rome for long, as he was back in Benevento with Louis II early in $871 .^{41}$ It is therefore far from certain whether Anastasius really produced the translation of the acts in Rome, or whether he already brought it to Rome ${ }^{42}$ - he could have worked with his Roman team at a number of places, for example Montecassino or Benevento proper. Indeed, we have no document attributed to him from Rome until summer $871 .{ }^{43}$

The letter was re-worked into a very fitting preface: Anastasius first and foremost sums up his mission to Constantinople, but actually, he does far more than that: he gives an ample summary of all papal policy of the past and present pontificate, as far as it related to the East. Accordingly, he starts the letter with a long list of charges against the former patriarch of Constantinople, Photios, whose deposition had recently been sanctioned at the council. ${ }^{44}$

Only after this longish »recap« does he explain the nature of his own personal mission as follows:

So when this venerable synod was being held, it happened that I your servant was present, sent by the pious emperor Louis with two other notable men, and carrying out an embassy ... arranging the marriage which both sides were hoping and preparing for, between the emperor Basil's son and the daughter of the said God-worshipping Augustus (Louis II). For in such a godly business, one which was believed without doubt to relate to the unity of both empires, indeed to the freedom of all Christ's church, your assent as supreme pontiff was particularly sought.

So by God's will it happened that I too rejoiced at the conclusion of so great an affair (the council) with the apostolic see's representatives, and that I, coming home with shouts of joy, could bring my sheaves with me (Ps. 125 (126),6). For some seven years, I had worked tirelessly on it, and by writing, I had broadcast the seeds of words throughout the world. It was in obedience to the supreme pontiffs, your predecessor

40 BAV Vat. Lat. 4965, fol. 22v. Leonardi, Anastasio bibliotecario, 171.

41 As is proven by the famous letter to Basil I, drafted by him in the name of Emperor Louis II, see Louis II, Letter to Basil, ed. Henze.

42 Contrary to Palma, Antigrafo/Apografo 324, it is not logical to assume that Anastasius would have waited for the papal envoys to arrive with the official copy to start producing his translation in the course of the year 870 .

43 Arnaldi, Anastasio Bibliotecario, antipapa, accordingly dates his return to office to summer 871. Accessed on 7 April 2021: www.treccani.it/enciclopedia/antipapa-anastasio-bibliotecario_\%28Enciclopedia-dei-Papi\%29/.

44 Anastasius, ep. to Hadrian II no. 5, ed. Laehr, 403-410, starting with the early tenure of Emperor Michael III and ending with the events of 870 . 
(Nicholas) and yourself, that I expounded almost everything that relates to the present affair and that has been issued by the apostolic see in Latin, whether contained in the codex of this synod or in other volumes. After I chanced to be at Constantinople for the reason I have mentioned, I provided many comforts for these representatives of yours, as they too bear witness. ${ }^{45}$

Anastasius, despite calling himself the pope's servant repeatedly, had actually been in the imperial city to negotiate a marriage alliance between his employer at the time, the Western emperor Louis II, and the Eastern emperor Basil I through Louis' only surviving daugher, Ermengard. The mission to Constantinople was led by Angilberga's relative Suppo, soon to be dux of Spoleto, and his seneschal count Everard..$^{46}$ While we know very little about the latter, Suppo was clearly very close to the empress and was surely chosen as an older relative of Ermengard, and not for his intimate knowledge of Eastern politics or his diplomatic skills - these requirements were instead to be filled by the experienced Anastasius.

The imperial embassy arrived in February 870 , just in time to enable them to take part at the last session of the council held there, as we will discuss later. Their mission was of the highest possible relevance for the Carolingian emperor, and it is no coincidence that Anastasius had been asked to be one of the leaders of it. Apart from his skills in Greek and his diplomatic experience, he had also been Ermengard's teacher and thus will have had a personal interest in the wellbeing of his pupil. ${ }^{47}$ Sadly, we have no more information than this about the negotiations in February 870.

45 Anastasius, ep. to Hadrian II, ed. Laehr, 410, trans. Davis, Lives of the Ninth-Century Popes, 280, n. 104. Igitur cum haec celebraretur venerabilis synodus, accidit me famulum vestrum missum a Hlndowico piissimo imperatore cum duobus aliis viris insignibus interesse ferentem etiam legationem ab apostolicis meritis decorato praesulatu vestro, causa nuptialis commercii, quod efficiendum ex filio imperatoris Basilii et genita praefati Dei cultoris augusti ab utraque parte sperabatur simul et parabatur. In tam enim pio negotio et quod ad utriusque imperii unitatem, immo totius Christi ecclesiae libertatem pertinere procul dubio credebatur, praecipue summi pontificii vestri quaerebatur assensus. Dei ergo nutu actum est, ut tanti negotii cum loci servatoribus apostolicae sedis et ipse fine gauderem et veniens fructuum in exultatione portarem manipulos, qui per septennium ferme pro eo indefesse laboraveram et per totum orbem verborum semina sedule scribendo disperseram. Nam pene omnia, quae ad praesens negotium pertinent quaeque a sede apostolica Latino sermone prolata sunt sive quae in huius synodi codice sive quae in aliis voluminibus continentur, ego summis pontificibus obsecundans, decessori scilicet vestro ac vobis, exposui et postmodum Constantinopoli pro praedicta causa reppertus non pauca in his vestris loci servatoribus, ut ipsi quoque testantur, solatia praestiti.

46 RI 1,3,1, ed. Zielinski and Böhmer, no. 301; accessed on 16 November 2020: www.regesta-imperii.de/id/o87002-00_1_o_1_3_1_4518_301. On Everard, see Hlawitschka, Franken, Alemannen, Bayern und Burgunder, no. 67, 180f: he was probably later a supporter of the Guidonian emperors Guy I (III) and Lambert. For Suppo III, see Hlawitschka, Franken, Alemannen, Bayern und Burgunder, no. 153, 171-173. And see Bougard, Les Supponides.

47 RI 1,3,1, ed. Zielinski and Böhmer, n. 290; accessed on 16 November 2020: www.regesta-imperii.de/id/o869-000o_1_0_1_3_1_4507_290; Flodoard, Historia Remensis ecclesiae 3, 27, ed. Heller and Waitz, 550. 
Consequently, modern research often concluded that negotiations must have failed ${ }^{48}$ but Anastasius' letter does not support this interpretation. It is far more plausible for the text above that in the course of 870 , Anastasius still believed that the marriage alliance was to be concluded soon: "causa nuptialis commercii, quod efficiendum ex filio imperatoris Basilii et genita praefati Dei cultoris augusti ab utraque parte sperabatur simul et parabatur", he says - the marriage is hoped for by both parties and prepared by both ${ }^{49}$ From the Carolingian point of view, it was probably to be concluded with the next mission, which was indeed sent in spring $871 .{ }^{\circ}$ By then, however, the political tides had shifted: first, even though the chronology remains unresolved, it is very likely that a Byzantine fleet arrived before Bari in late summer $870 .{ }^{51}$ Its commander, Niketas Ooryphas, ${ }^{52}$ seems to have been under the impression that he would already take Ermengard to Constantinople. The misunderstanding culminated in a diplomatic éclat, information about which we can find in yet another letter penned by Anastasius, though this time in the name of Emperor Louis himself. This is the famous letter written to Basil I, preserved in the anonymous Chronicle of Salerno. Therein we learn that both Basil and his envoys to the West had refused to acknowledge Louis' imperial rank at a later point. ${ }^{53}$ This cannot have happened during Anastasius' Eastern mission, otherwise we would surely have heard of it in the earlier letter. ${ }^{54}$ We also learn that the political alliance had not brought the desired results for both sides: Louis had taken Bari in February 871, but the naval support from the Byzantines had been minimal - in fact, he had had to resort to Slavic allies to block reinforcements for Bari. As a result of these events, the marriage alliance was called off by the Carolingian side. ${ }^{55}$

In 870, however, this was, of course, not known, and, as we learn from the letter to Hadrian, not even expected. Though Anastasius does not tell Pope Hadrian much about this part of his mission, we can discover a lot when we take a close look at the passage. The most important factor for the geopolitical importance of the message is Anastasius' notion that the marriage negotiations could be seen as "related to the unity of both empires " - ad utriusque imperii unitatem..$^{56}$ He used this peculiar expression, even though he must have been aware that this aspect would be a little worrying for the papacy. Since the 730 s at the latest, the popes did not desire any direct influence of the Eastern emperors in the West, let alone in Rome itself. In fact, they did everything in their power to stay on agreeable terms - but

48 For example, RI 1,3,1, ed. Zielinski and Böhmer, no. 301.

49 Anastasius, ep. to Hadrian II, ed. Laehr, 410.

50 RI 1,3,1, ed. Zielinski and Böhmer, no. 326.

51 See Kislinger, Erster und zweiter Sieger; and see below, n.52.

52 Niketas Ooryphas \#25696, in: Prosopographie der mittelbyzantinischen Zeit, accessed on 18 May 2020: dbdegruyter-com.uaccess.univie.ac.at/view/PMBZ/PMBZ27850.

53 Louis II, Letter to Basil, ed. Henze and Westerbergh, Chronicon Salernitanum, 107-21.

54 Despite that very clear argument from a letter that can be dated with high certainty, the historians upholding the traditional chronology that has the fallout with the East start already in 869 are more numerous. For a summary and support of the traditional timeline, see Kolditz, Gesandtschaften, Briefe und Konzilien. But see Kislinger, Erster und zweiter Sieger, for a compelling refutation of that timeline. In my forthcoming monograph on Louis II and his time, I shall address this question in more detail.

55 Louis II, Letter to Basil, ed. Henze.

56 Anastasius, ep. to Hadrian II, ed. Laehr, 410. 
nevertheless to keep Constantinople as far away as possible. ${ }^{57}$ It is therefore unlikely that anyone in the papacy would have relished the thought that a son of the new, upstart emperor Basil might one day be able to reign in Italy. We cannot say today why Anastasius even thought that this may be good news - but obviously it was to him and he expected Hadrian to feel the same way. It seems that no one in the West even considered Basil's son ruling Italy after Louis II's death a real possibility, and maybe it would have been regarded far-fetched by 870 . Later in her life, we meet Ermengard again as a very strong woman ${ }^{58}$ who wielded a lot of power - and it is not impossible that Anastasius, as her teacher for a short time, had already recognized that strength in her. Maybe it was this confidence in the princess and the Carolingians in general that led Anastasius to believe in his core mission, but ultimately, we will never be able to tell.

What we do know, however, is that compared to the rest of the letter, the imperial mission seems, in Anastasius' eyes, to be the successful part. This means a lot given that the council of 869/70 was in many respects a triumph for the Western churches. ${ }^{59}$

In the letter at least, Anastasius had other concerns, as we can already see in the longer cited section: in Anastasius' opinion the breaking points in early 870 lay mainly in the ecclesiastic field. It is thus not conspicuous that Anastasius mentions no other imperial personnel. Indeed, not even Basil's son or Ermengard are mentioned by name (which has the consequence that we do not know which of Basil's sons was meant to be married). Both names will have been known to the addressee, of course, but it underscores the character of Anastasius that he only mentions this in passing. The letter was meant to document the problems Anastasius must have seen as most pressing in great detail: the schism Photios had brought about, the Bulgarian question and the question of the acts of the synod. Anastasius verbosely described how he had been excluded from the negotiations on Bulgaria in particular and how his presence would have enhanced the papal position. ${ }^{60}$ For the acts of the synod, the

57 Noble, Republic of St. Peter; Gantner, Freunde Roms und Völker der Finsternis, esp. 60-138; Gantner, Label 'Greeks'; Gantner, Romana urbs; Gantner, Eighth-century papacy; Dell'Acqua and Gantner, Resenting Byzantine Iconoclasm.

58 Bougard, Ermengarda, regina di Provenza: Ermengard married Boso of Provence shortly after her father's death and was key in his establishment of a separate kingdom in southern Francia. She was also the mother of Emperor Louis III (the Blind),

59 Chrysos, Council of Constantinople.

60 Anastasius, ep. to Hadrian II, ed. Laehr, 411-414. 
letter mainly explains how its author had been essential in the preservation of the acts' text for the papacy - while the pope's own embassy lost the original copy of the acts meant to be brought to the Lateran. For this, Emperor Basil is blamed at least implicitly, as he had failed to provide for a secure journey for the papal delegation. Still, it becomes equally clear that Anastasius and the imperial embassy had taken better precautions than the pope's men - and had been right to do so. ${ }^{61}$

\section{Anastasius, Power Broker Par Excellence?}

The letter from 870 is very much dedicated to Anastasius' self-promotion, urgently needed to regain fully the favour of Pope Hadrian. He negotiates with the Byzantine emperor for the Carolingian emperor. Besides this, he also grasped the opportunity to represent the papacy vis-à-vis the Eastern ecclesiastical elites - certainly no easy task. Anastasius did this, even though he had not received an official mandate from the pope. He calls himself the pope's servant in the letter, but really he was at the council by chance. What is more, he underlines his usefulness and thereby justifies his unsanctioned actions. He even informs Hadrian and the world about his personal motivations for doing so, explaining that already under Pope Nicholas he had considered the fight against the former patriarch Photios as his personal project. Anastasius was an erudite diplomat and ecclesiastic, essentially writing an application to be taken back into papal service. He did this while working for Emperor Louis, whose daughter he seems to have instructed as her teacher during these years. We thus see Anastasius as a diplomat, even as a power broker between East and West. ${ }^{62} \mathrm{He}$ was one of the most important authors of letters sent by the popes Nicholas I (858-867), Hadrian II (867-872) and John VIII (872-882), being at times nearly solely responsible for the formulation of the Eastern policy. ${ }^{63}$ The same seems to apply for Louis II's correspondence with the Byzantine Empire, as far as we can tell from the very scant evidence.

And even though he personally certainly caused discord between the imperial court and the Lateran at some points during his long career, he also worked as a power broker between those institutions he knew so well - incidentally showing us that a power broker does not need to be functional or even successful all the time. ${ }^{64}$ That he may even have been of service

61 Anastasius, ep. to Hadrian II, ed. Laehr, 410: Nam pene omnia, quae ad praesens negotium pertinent quaeque a sede apostolica Latino sermone prolata sunt sive quae in huius synodi codice sive quae in aliis voluminibus continentur, ego summis pontificibus obsecundans, decessori scilicet vestro ac vobis, exposui et postmodum Constantinopoli pro praedicta causa reppertus non pauca in his vestris loci servatoribus, ut ipsi quoque testantur, solatia praestiti. Qui etiam diversos hominum eventus considerans gesta huius synodi, quae apostolicae sedis loci servatores in uno volumine secum portaturi conscripserant, in altcro codice transcripta Romam aeque deferre proposui. Unde factum est, ut eisdem loci servatoribus praedones incidentibus et codicem ipsum cum omnibus supellectilibus suis amittentibus ego codicem, quem detuleram, Romam vexisse dinoscerer, quem sanctitas vestra grato suscipiens animo mihi ad transferendum in Latinam tradidit dictionem. Ad quod opus ego idoneum esse me denegavi, licet in interpretandis ex Achivo in Romanum sermonem scripturis praesenti tempore quoddam conamen arripere nitar et nonnulla iam ad aedificationem plurimorum et praecipue vestri decessoris hortatu interpretatus edidisse dinoscar.

62 For the theoretical approach used, see Gantner, Eighth-century papacy, esp. 245-247; Hinderaker, Translation and cultural brokerage.

63 See Perels, Papst Nikolaus I. und Anastasius Bibliothecarius, 242-316.

64 See Hinderaker, Translation and cultural brokerage, 358. Going beyond Hinderaker's definition of cultural brokerage, however, Anastasius' deeds possibly did supersede his original standing and Roman origins. 
for Louis in this respect is suggested by the fact that after his return to papal service in 870 or 871, Hadrian II unfalteringly supported Louis II's cause ${ }^{65}$ once Louis was released after having been imprisoned in southern Italy in late summer 871 for 40 days ${ }^{66}$ - though I have to admit, that Anastasius' influence cannot be proven, due to our relative lack of sources for these years.

\section{Conclusion}

In this article, we have but rushed through Anastasius' life and acquired only glimpses of what he accomplished. He was a complex figure, maybe even a polymath. Mostly, we have met him at one of the last points of intersection he faced during his career. In the few years between 868 and 872, he was deprived of office and status, but remained a sought-after teacher. He was then sent on his most important diplomatic mission, but, as it turned out, also the most important cultural mission of his lifetime by the emperor, only to return into papal service thereafter. During these vicissitudes, all his actions stayed firmly connected to his role as a broker between East and West, between the past and the present through his cultural work and between the lay world and the ecclesiastical sphere.

We have no reason to doubt his personal claim that he had indeed been the most important author (dictator) of the papal letters dealing with Eastern affairs - after all, why should he have overstated his contribution when writing to Hadrian II, who had himself been part of the papal administration and would have known the truth anyway? Given this evidence, he was ultimately among the more successful papal diplomats of the early Middle Ages. No wonder then, that he was also employed in that profession during his exile by the imperial court. It was a lucky coincidence that he even managed to serve his interim as well as his long-time lord during his mission to Constantinople in 870. As we have seen, the official leaders of the mission were (or in one case at least seem to have been) close to the empress, the emperor or the princess, but they were in all probability not equipped to lead negotiations with the Constantinopolitan court or even Emperor Basil himself. For this, they will have needed Anastasius with them. And Anastasius, who will thus have been heavily involved in the marriage question, told the pope that this part of the mission had gone well. He was euphoric enough even to invoke an idea of a unity of the Eastern and Western empires under the couple to be - possibly he knew Ermengard well enough to appreciate that she would not simply be dominated by any husband. In the much more famous letter from 871 Anastasius wrote in the name of Louis II and we can sense his frustration with the course that events had taken as much as his employer's. The "Greeks" had already insulted him and the papal delegation in 870 , and now they had insulted the imperial side as well. Ultimately, therefore, the librarian and diplomat will have come to see this part of his career as a failure, but quite probably not as his personal defeat. His comment only a few years later in his translation of the acts of the Second Council of Nicea, that parts had been »falsified, as is the custom of the Greeks « shows that he still held a personal grudge ${ }^{67}$ His efforts were partly in vain. Constantinople sacrificed an alliance with the Western empire for short term gains in southern Italy

65 Grotz, Erbe wider Willen, 300-303.

66 Granier, La captivité.

67 See Lamberz, "Falsata Graecorum more«?. Indeed, the Greeks acts of the 787 council seem to have left out a big part of a letter by Pope Hadrian I on purpose. 
and in the Balkans - and thereby achieved territorial gains and renewed political influence mostly by luck, while it had to accept the loss of Syracuse in 878 and Sicily a little later as a very high price for it. Louis II, together with Anastasius, had sacrificed the same alliance as well, mostly due to hierarchical questions, losing the south for the north Italian kingdom for good. And the papacy, while it gained a better standing in the church temporarily, lost Bulgaria to the Eastern church and had to accept another tenure of the hated Patriarch Photios only a few years later.

Anastasius still (probably) witnessed many or all of these developments before his death and none of them were ultimately his fault - and in none of the developments will he have been blameless. Still, for him personally, things turned out well. He was taken back into papal service in late spring or summer 871. In this year he was on a mission for Hadrian to Naples before August. ${ }^{68}$ For Pope John VIII, who ascended to the papal throne in 872, he served as bibliothecarius again. He is even mentioned as head of the chancellery in many of his letters and privileges by then. Anastasius died in 878 or 879 as a quite old man in Rome and will, in all probability, have considered this last stretch of his career as its high point. ${ }^{69}$ We have seen him, instead, in the last of several turbulent stages, when he rose to his highest »international « or super-regional importance all the same. Over a period of about three years he worked at no less than three of the most important courts of his time: in Rome, at the mobile, impromptu Carolingian court of the late 860s and in Constantinople. He acted as a broker between all of them - during his stay at the Byzantine capital even simultaneously and through his longish letter, he provided us with a first-hand account of one of the most fascinating diplomatic missions of the ninth century.

$68 \mathrm{~J}$, no. 6284, ed. Werner et al., 162-163. The last time Anastasius is attested in Rome before this is 12th October 868, at his trial in front of Hadrian II: see J3, no. 6190, ed. Werner et al., 147.

69 Arnaldi, Anastasio Bibliotecario, antipapa. 


\title{
References
}

\author{
Abbreviations \\ $\mathrm{BAV}=$ Biblioteca Apostolica Vaticana \\ LP = Liber Pontificalis \\ MGH EE = Monumenta Germaniae Historica Epistolae \\ MGH SS = Monumenta Germaniae Historica Scriptores \\ $\mathrm{RI}=$ Regesta Imperii \\ $\mathrm{J}^{3}=$ Regesta Pontificum Romanorum vol. 3
}

Annales Bertiniani, ed. Félix Grat, Jeanne Vielliard, Suzanne Clémencet, Les Annales de Saint-Bertin (Paris 1964); trans. J. L. Nelson, The Annals of St-Bertin, Manchester Medieval Sources Series 2 (Manchester 1991).

Anastasius, ep. 3, to Ado, ed. Gerhard Laehr, MGH EE VII (Berlin 1928) 400-401.

Anastasius, ep. 5, to Hadrian II, ed. Gerhard. Laehr, MGH EE VII (Berlin 1928) 403-415.

Anastasius, Gesta sanctae ac universalis octavae synodi quae Constantinopoli congregata est, ed. Claudio Leonardi and Antonio Placanica, Edizione nazionale dei testi mediolatini Serie 1, 16 (Firenze: Sismel edizioni del Galluzzo, 2012).

Arnaldi, Girolamo, Come nacque la attribuzione ad Anastasio del "Liber Pontificalis«: Studi e ricerche su Anastasio Bibliotecario, 1 (Rome, 1963).

Arnaldi, Girolamo, Anastasio Bibliotecario, antipapa, in: Massimo Bray (ed.), Enciclopedia dei papi (Rome, 2000). Accessed on 7 April 2021: www.treccani.it/enciclopedia/antipapa-anastasio-bibliotecario_\%28Enciclopedia-dei-Papi\%29/.

$B A V$ Vat. Lat. 1342 = Rome, Biblioteca Apostolica Vaticana, Vaticanus Latinus 1342.

BAV Vat. Lat. 4965 = Rome, Biblioteca Apostolica Vaticana, Vaticanus Latinus 4965.

Bougard, François, Ermengarda, regina di Provenza, Dizionario Biografico degli Italiani, vol. 43. Accessed on 16 November 2020: www.treccani.it/enciclopedia/regina-di-provenza-ermengarda_(Dizionario-Biografico).

Bougard, François, Les Supponides: échec à la reine, in: François Bougard (ed.), Les élites au haut Moyen Âge. Crises et renouvellements (Turnhout, 2006) 381-402.

Chiesa, Paolo, Filologia e politica nella Roma di Anastasio Bibliotecario, Rivista di storia della chiesa in Italia 67 (2013) 543-568.

Chiesa, Paolo, Scopi e destinatari delle traduzioni dal greco nel medioevo latino: una prospettiva politica, in: Stefano Costa, Federico Gallo (eds.), Miscellanea graecolatina 3 (2015) 117-133. Accessed on 7 April 2021: www.torrossa.com/it/resources/an/3034442.

Chrysos, Evangelos K., The Council of Constantinople in 869-70: a minority council, in: Annuarium Historiae Conciliorum 49 (2020) 138-161.

Davis, Raymond, The Lives of the Ninth-Century Popes (Liber Pontificalis). The Ancient Biographies of Ten Popes from A.D. 817-891, Translated Texts for Historians 20 (Liverpool, 1995).

Dell'Acqua, Francesca and Clemens Gantner, Resenting Byzantine iconoclasm. Its early reception in Italy through an inscription from Corteolona, in: Medieval Worlds 9 (2019) 160-186.

Fanning, Steven C., Imperial diplomacy between Francia and Byzantium: The letter of Louis II to Basil I in 871, in: Cithara 34 (1994) 3-17.

Flodoard, Historia Remensis ecclesiae, ed. Johannes Heller and Georg Waitz, MGH SS XIII (Hanover, 1881) 
Forrai, Reka, Anastasius Bibliotecarius and his textual dossiers: Greek collections and their Latin transmission in 9th century Rome, in: Stéphane Gioanni (ed.), L'Antiquité tardive dans les collections médiévales. Textes et répresentations (2008) 319-337.

Forrai, Reka, The Interpreter of the Popes: The Translation Project of Anastasius Bibliothecarius (Budapest, 2008).

Forrai, Reka, Greek at the papal court during the Middle Ages, in: Karen L. Fresco and Charles D. Wright (eds.), Translating the Middle Ages (Farnham, 2012) 161-170.

Forrai, Reka, The sacred nectar of the deceitful Greeks. Perceptions of Greekness in ninth century Rome, in: Andreas Speer (ed.), Knotenpunkt Byzanz. Wissensformen und kulturelle Wechselbeziehungen (Berlin, 2012) 71-84.

Gantner, Clemens, The label 'Greeks' in the papal diplomatic repertoire in the eighth century, in: Walter Pohl and Gerda Heydemann (eds.), Strategies of Identification. Ethnicity and Religion in Early Medieval Europe (Turnhout, 2013) 303-349.

Gantner, Clemens, Freunde Roms und Völker der Finsternis: Die päpstliche Konstruktion von Anderen im 8. und 9. Jahrhundert (Vienna, 2014).

Gantner, Clemens, Romana urbs: levels of Roman and imperial identity in the city of Rome, Early Medieval Europe 22 (2014) 461-475.

Gantner, Clemens, The eighth-century papacy as cultural broker, in: Clemens Gantner, Rosamond McKitterick and Sven Meeder (eds.), The Resources of the Past in Early Medieval Europe (2015) 245-261.

Gantner, Clemens, Kaiser Ludwig II. von Italien und Byzanz, in: Falko Daim, Dominik Heher and Claudia Rapp (eds.), Menschen, Bilder, Sprache, Dinge. Wege der Kommunikation zwischen Byzanz und dem Westen 2 (Mainz, 2018) 103-112.

Gantner, Clemens, »Our Common Enemies Shall Be Annihilated!« How Louis Ils relations with the Byzantine Empire shaped his policy in southern Italy, in: Kordula Wolf and Klaus Herbers (eds.), Southern Italy as Contact Area and Border Region during the Early Middle Ages (Cologne, 2018) 295-314.

Gantner, Clemens, Silence of the popes: Why King Pippin of Italy was hardly ever mentioned in the papal writings of the time, in: Giuseppe Albertoni and Francesco Borri (eds.), Spes Italiae: il regno di Pipino, $i$ Carolingi e l'Italia (781-810) (Turnhout, 2021 in print).

Granier, Thomas, La captivité de l'empereur Louis II à Bénévent (13 août-17 septembre 871) dans les sources des IXe-Xe siècles, in: Claude Carozzi und Huguette Taviani-Carozzi (eds.), Faire l'événement au Moyen Âge (Aix-en-Provence, 2007) 13-39.

Grotz, Hans, Erbe wider Willen. Hadrian II. (867-872) und seine Zeit (Vienna, 1970).

Henze, Walter, Über den Brief Kaiser Ludwigs II. an den Kaiser Basilius I., Neues Archiv der Gesellschaft für ältere deutsche Geschichtskunde 35 (1910) 661-676.

Hinderaker, Eric, Translation and cultural brokerage, in: Neal Salisbury and Philip J. Deloria (eds.), A Companion to American Indian History, Blackwell Companions to American History (Malden, MA, 2002) 357-375.

Hlawitschka, Eduard, Franken, Alemannen, Bayern und Burgunder in Oberitalien (774-962): Zum Verständnis der fränkischen Königsherrschaft in Italien, Forschungen zur oberrheinischen Landesgeschichte 8 (Freiburg im Breisgau, 1960).

Kislinger, Ewald, Erster und zweiter Sieger. Zum byzantinisch-karolingischen Bündnis bezüglich Bari 870-871, Zbornik radova Vizantoloskog Instituta 50 (2013) 245-258. 
Kolditz, Sebastian, Gesandtschaften, Briefe und Konzilien in den Beziehungen Ludwigs II. von Italien zu Byzanz, in: Sebastian Roebert et al. (eds.), Von der Ostsee zum Mittelmeer. Forschungen zur mittelalterlichen Geschichte für Wolfgang Huschner (Leipzig, 2019) 289310.

Laehr, Gerhard, Die Briefe und Prologe des Bibliothekars Anastasius, Neues Archiv der Gesellschaft für ältere deutsche Geschichtskunde 47 (1928) 416-468.

Lamberz, Erich, "Falsata Graecorum more«?: Die griechische Version der Briefe Papst Hadrians I. in den Akten des VII. Okumenischen Konzils, in: Claudia Sode, Sarolta A. Takács (eds.) Novum millennium: Studies in Byzantine History and Culture Presented to Paul Speck (Aldershot, 2001) 213-230.

Leonardi, Claudio, Anastasio bibliotecario e l'ottavo concilio ecumenico, Studi medievali 8 (1967) 59-192.

Liber Pontificalis, ed. Louis Duchesne, Le Liber Pontificalis. Texte, introduction, commentaire, 3 vols. (Paris 2 1955-1957, vol. 3 ed. Cyrille Vogel); trans. Raymond Davis, The Lives of the Ninth-Century Popes (Liber Pontificalis). The Ancient Biographies of Ten Popes from A.D. 817-891, Translated Texts for Historians 20 (Liverpool, 1995).

Louis II, Letter to Basil, ed. Walter Henze, MGH EE VII (Berlin, 1928) 385-394.

Mango, Cyril A. and Roger D. Scott, The Chronicle of Theophanes Confessor: Byzantine and Near Eastern History AD 284-813 (Oxford, 2006).

Mansi, Giovanni D., Sacrorum Conciliorum. Nova et Amplissima Collectio, ed. Jean B. Martin and Louis Petit (Paris, 1901).

Neil, Bronwen, Seventh-century Popes and Martyrs: The Political Hagiography of Anastasius Bibliothecarius, Studia antiqua Australiensia 2 (Turnhout, 2006).

Noble, Thomas F. X., The Republic of St. Peter: The Birth of the Papal State, 680-825, The Middle Ages (Philadelphia, PA, 1984).

Noble, Thomas F. X., The declining knowledge of Greek in eight- and ninth-century papal Rome, Byzantinische Zeitschrift 78 (1985) 56-62.

Noble, Thomas F. X., Pope Nicholas I and the Franks: politics and ecclesiology in the ninth century, in: Rob Meens (ed.) Religious Franks. Religion and Power in the Frankish Kingdoms: Studies in Honour of Mayke de Jong (Manchester, 2016) 472-488.

Palma, Marco, Antigrafo/apografo. La formazione del testo latino degli atti del concilio costantinopolitano dell'869-70, in: Cesare Questa and Renato Raffaelli (eds.), Atti del Convegno internazionale Il libro e il testo (Urbino, 1984) 307-335.

Perels, Ernst, Papst Nikolaus I. und Anastasius Bibliothecarius. Ein Beitrag zur Geschichte des Papsttums im 9. Jahrhundert (Berlin, 1920).

Prosopographie der mittelbyzantinischen Zeit (Berlin, 1999).

Regesta Imperii I. Die Regesten des Kaiserreichs unter den Karolingern 751-918 (926). Vol 3, Die Regesten des Regnum Italiae und der burgundischen Regna. Tl. 1. Die Karolinger im Regnum Italiae 840-887 (888), ed. Herbert Zielinski and J.F. Böhmer, Regesta Imperii 3 (Cologne, 1991).

Regesta Pontificum Romanorum ab condita ecclesia ad annum post Christum natum MCXCVIII. Vol 3 ( $a b$ a. DCCCXLIV usque ad a. MXXIV), ed. Judith Werner, Waldemar Könighaus, Philipp Jaffé and Klaus Herbers (Göttingen, 2017).

Sansterre, Jean-Marie, Les moines grecs et orientaux à Rome aux époques byzantine et carolingienne (milieu du VIe s. - fin du IXe s.), Mémoires de la Classe des lettres / Académie Royale de Belgique. Collection in-8o, 2e série, 66 (Brussels, 1983) fasc. 1. 
Schmid, Anne, Roms karolingische Minuskel im neunten Jahrhundert, Schriftenreihe Studien zur Geschichtsforschung des Mittelalters 15 (Hamburg, 2002).

Tabachovitz, David, Sprachliches zur lateinischen Theophanesübersetzung des Anastasius Bibliothecarius, Byzantinische Zeitschrift 38 (1938) 16-22.

Westerbergh, Ulla, Chronicon Salernitanum. A Critical Edition with Studies on Literary and Historical Sources and on Language, Acta Universitatis Stockholmiensis. Studia latina Stockholmiensia 3 (Stockholm, 1956). 